\title{
Development of ICP-AES Method for the Determination of Common Metallic and Rare Earth Elements in High-Level Radioactive Liquid Waste Solutions
}

\author{
S.K. Thulasidas, V.C. Adya, T.K. Seshagiri*, Mithlesh Kumar, M.K. Bhide, and S.V. Godbole \\ Radiochemistry Division, Bhabha Atomic Research Centre, \\ Trombay, Mumbai - 400 085, India
}

\section{INTRODUCTION}

The success and public acceptance of the nuclear energy program is heavily dependent on the safe management of the radioactive waste generated at various stages of the program (1). In a reprocessing plant for spent nuclear fuel, the spent fuel is dissolved in concentrated $\mathrm{HNO}_{3}$ and plutonium and un-burned uranium are removed in the chemical separation process. The remaining solution contains more than $99 \%$ of the non-volatile fission product elements, impurities from cladding materials, corrosion products, traces of unseparated plutonium, and most of the transuranic elements.

The reprocessing waste is called high-level radioactive liquid waste (HLLW). The HLLW is generally concentrated by evaporation and stored in aqueous $\mathrm{HNO}_{3}$ solution in high integrity stainless steel tanks. Internationally, glass is the choice for incorporating and immobilizing the hazardous radionuclides in HLLW because of the good potential durability and technical maturity. Almost a decade ago, the HLLW arising from the commercial reprocessing plants were converted to borosilicate glasses in the vitrification plants in France and the United Kingdom. The chemical analysis of the vitrified products produced in the industrial vitrification plants is important for supporting the characterization tests of

\footnotetext{
*Corressponding author
}

E-mail: giritks@gmail.com

\begin{abstract}
An inductively coupled plasma atomic emission spectrometry (ICP-AES) method has been developed for the trace metal characterization of highlevel liquid waste solutions originating from reactor fuels of burn-up varying from 1000 to 15,000 MWD per ton. After optimization of various analytical parameters, the method was validated by analysis of three synthetic samples containing elements in the composition range as expected in high-level radioactive liquid waste (HLLW). The analytical results obtained by ICP-AES from simulated highlevel liquid waste (SHLW) of a pressurized heavy water reactor (PHWR), research reactor (RR), fast breeder reactor (FBTR), and high-level radioactive liquid waste (HLLW) from the Plutonium Resprocessing Plant (PREFRE) and Waste Immobilisation Plant (WIP) in Tarapur, India, are also included.
\end{abstract}

actual high-level radioactive glass. The separation and estimation of metal ions from high-level liquid waste is a challenging task and generally requires more than one technique for their quantification. The determination of actinides and other radioactive elements is predominantly carried out by the radiometric technique. However, the determination of non-radioactive elements is performed by other techniques such as inductively coupled plasma atomic emission spec- trometry (ICP-AES), inductively coupled plasma mass spectrometry (ICP-MS), and of late ion chromatographic (IC) techniques (2-5). Of these, ICP-AES and ICP-MS require separation of the ions from the matrix before their detrmination. Also, the presence of a host of other elements can be a limitation in the determination of various elements due to chemical, spectral, as well as other interferences. Characterization of the HLLW is also of paramount importance prior to the development of actinide portioning. Actinide portioning selectively removes minor actinides along with trivalent lanthanides. The separation step involves the use of reagents such as octyl(phenyl) N,N-diisobutyl carbomyl methylene phosphine oxide (CMPO), N,N-dimethyl-N,N'-dibutyl tetramalonamide (DMDBTDMA), and N,N,N',N'-tetraoctyl diglycolamide (TODGMA). The success of the actinide partitioning step can be evaluated by estimating the elements present in HLLW before and after this separation step (2). The elements required to be determined in the various HLLWs were selected from the standpoint of the process pickups, fission products built up expected as per burn-up, and type of fuel. In particular this includes the elements $\mathrm{Ba}, \mathrm{Ce}, \mathrm{La}, \mathrm{Mo}, \mathrm{Nd}$, Pd, Pr, Rh, Ru, Sr, Y, Dy, Eu, Gd, $\mathrm{Sm}$, etc., as fission products, uranium left-over fissile material, and the elements $\mathrm{Na}, \mathrm{Al}, \mathrm{Mg}, \mathrm{Cr}, \mathrm{Fe}, \mathrm{Ni}$, $\mathrm{Zr}$, etc., as associated process pickups. Since many of these elements have a complex spectra, it is essential to identify either interferencefree lines at the expected levels of 
these elements or obtaining correction factors for spectral interference, if any.

For analytical purposes, the separation procedure developed should be such that we should be able to estimate trace levels of the analyte elements but at the same time separate out the major matrix quantitatively. This requires that the regularly established chemical separation procedure needs to be re-evaluated for its application to analytical purposes. Methods have been developed in our laboratory for determining common impurities and rare earths in complex matrices such as uranium and plutonium using different extractants such as Tri-n-octyl amine, Tributyl phosphate, and cyanex (6-10).

In the present work, the focus during the development of the analytical method involving ICP-AES was on (i) identifying appropriate analytical lines and correction factors, if any, (ii) developing a separation procedure for removal of uranium since it was known to have large spectral interferences, and (iii) a sample handling procedure with appropriate dilution and separation for minimizing the radiation dose. The radiation dose of the waste solution was reduced by radiochemical separation of cesium from the HLLW by solvent extraction with chlorinated cobalt dicarbollide, dissolved in $20 \%$ nitrobenzene in xylene, the details of which are discussed later. Based on this, an analytical method was developed for the characterization of HLLWs of different origin and the method was validated by analysis of three synthetic samples of simulated high-level waste solutions (SHLWs). The results of the ICP-AES analysis of three SHLW samples and four actual HLLW samples are included.

\section{EXPERIMENTAL}

\section{Instrumentation}

The instrument used in the present studies was a Jobin Yvon Ultima ICP-AES (Longjumeau Cedex, France), equipped with an R.F. generator at a frequency of 40.68 MHz. The monochromator consisted of two holographic gratings with 4320 grooves $/ \mathrm{mm}$ and 2400 grovees $/ \mathrm{mm}$, covering different ranges with back-to-back vertical fitting. The sample introduction included a Meinhard ${ }^{\circledR}$ TR 50-C1 glass nebulizer and a cyclonic spray chamber. The instrumental operating conditions are listed in Table I.

The simulated high-level liquid wastes (SHLWs) corresponding to a research reactor [RR] (burn-up = $1000 \mathrm{MWD} / \mathrm{t}$ ) and pressurized

\section{Atomic Spectroscopy 1 Vol. 33(5), Sept./Oct. 2012}

heavy water reactor (PHWR) (burnup $=6700 \mathrm{MWD} / \mathrm{t}$ ) were prepared at the Waste Management Division, BARC. The SHLW for the fast breeder reactor [FBR] (burn-up = $150,000 \mathrm{MWD} / \mathrm{t}$ ) was prepared by the chemistry group, IGCAR, Kalpakkam, India. A 10-mL amount of SHLW solution sample was taken for the analysis. Since the PHWR contained significant amounts of uranium, its separation was carried out by solvent extraction (three contacts) into 30\% TBP in dodecane prior to ICP analysis. In other SHLW samples, i.e., the research reactor (RR) and fast breader reactor (FBR), uranium was present at much smaller concentrations, thus permitting the direct analysis of metallic constituents by ICP-AES. Calibration in ICP-AES was carried out using multi-point standardiza-

TABLE I

Instrumental Operating Conditions

\begin{tabular}{|c|c|}
\hline Spectrometer & $\begin{array}{l}\text { Jobin Yvon (ULTIMA), } \\
\text { High Resolution Sequential spectrometer }\end{array}$ \\
\hline \multicolumn{2}{|l|}{ Optics: } \\
\hline Focal Length & $1 \mathrm{M}$ \\
\hline Grating & $\begin{array}{l}\text { Two holographic gratings with } 4320 \text { grooves/mm } \\
\text { and } 2400 \text { grooves/ mm covering different range } \\
\text { with back-to-back vertical fitting }\end{array}$ \\
\hline Range & (i) $180-450 \mathrm{~nm}$; (ii) $400-800 \mathrm{~nm}$ \\
\hline R.F. Generator & Model Ultima \\
\hline Frequency & $40.68 \mathrm{MHz}$ \\
\hline Forward Power & $1.0 \mathrm{KW}$ \\
\hline Reflected Power & $<10 \mathrm{~W}$ \\
\hline Nebulizer & $\begin{array}{l}\text { Meinhard C } 1 \text { type concentric nebulizer } \\
\text { with a cyclonic chamber }\end{array}$ \\
\hline Plasma Torch & $\begin{array}{l}\text { Demountable assembly with configuration } \\
\text { with three co-axial concentric tubes: } \\
\text { central injector of alumina and } \\
\text { the other tubes of silica glass }\end{array}$ \\
\hline \multicolumn{2}{|l|}{ Argon Gas: } \\
\hline Plasma Gas Flow & $12 \mathrm{~L} / \mathrm{min}$ \\
\hline Cooling Gas Flow & $0.2 \mathrm{~L} / \mathrm{min}$ \\
\hline Nebulizer Pressure & 3 bars \\
\hline Nebulizer Flow & $0.85 \mathrm{~L} / \mathrm{min}$ \\
\hline Pressure of Manometer & 6 bar \\
\hline Pump Speed & 20 rotations $/ \mathrm{min}$ \\
\hline
\end{tabular}


tion. The analytical lines used for the different elements in the samples studied are given in Table II. In case of HLLW samples, chlorinated cobalt dicarbolide (CCD) separation was carried out to separate the Cs, the details of which are discussed in a later section. The reagents used in the preparation of the standards and samples were of electronic grade purity. The water used was doubly distilled in a quartz apparatus prior to its use.

\section{RESULTS AND DISCUSSION}

The HLLW samples obtained from the processing of spent reac- tor fuels vary in their burn-up and fuel composition. They are also expected to contain different elements with varying concentrations. Such high-level radioactive liquid waste (HLLW) solutions are known to contain high concentrations of certain elements (such as $\mathrm{Fe}, \mathrm{Na}$, $\mathrm{Cr}, \mathrm{K}, \mathrm{Mn}, \mathrm{Cr}, \mathrm{Ba} \mathrm{U}, \mathrm{Ni}, \mathrm{Zr}$ ) and certain lanthanides (such as $\mathrm{Ce}, \mathrm{La}$, Nd, Pr, Sm, Y, etc.).

ICP-AES, being a multi-element analytical technique, can be fruitfully employed to analyze such samples mainly for the concentration of non-radioactive elements. However, this requires optimization of experimental parameters. The parameters, like analytical lines, need to be chosen depending on the concomitant elements and their possible spectral interferences. As spectral interference from uranium is well known whenever its content exceeds $\sim 50 \mathrm{~g} / \mathrm{mL}$, an appropriate separation procedure for its removal without losses in analyte concentration is also required to be developed. The well-known TBP extraction (8-10) was employed to separate uranium in PHWR SHLW samples. In other SHLW samples, such as RR and FBR, uranium was not present in appreciable amounts,

TABLE II

Analysis of Synthetic Samples

\begin{tabular}{cccccccc}
\hline Element & $\begin{array}{c}\text { Wavelength } \\
(\mathrm{nm})\end{array}$ & $\begin{array}{c}\mathrm{S}-1(\mu \mathrm{g} / \mathrm{mL}) \\
\text { Amount } \\
\text { added }\end{array}$ & $\begin{array}{c}\text { Amount } \\
\text { determined }\end{array}$ & $\begin{array}{c}\text { S-2 }(\mu \mathrm{g} / \mathrm{mL}) \\
\text { Added }\end{array}$ & $\begin{array}{c}\text { Amount } \\
\text { determined }\end{array}$ & $\begin{array}{c}\mathrm{S}-3(\mu \mathrm{g} / \mathrm{mL}) \\
\text { Amount } \\
\text { added }\end{array}$ & $\begin{array}{c}\text { Amount } \\
\text { determined }\end{array}$ \\
\hline $\mathrm{Al}$ & 309.27 & 20 & $19.8 \pm 0.2$ & 40 & $39.9 \pm 0.4$ & 80 & $82 \pm 1.2$ \\
$\mathrm{Ba}$ & 455.40 & 5 & $5.1 \pm 0.1$ & 10 & $10.1 \pm 0.3$ & 20 & $20.2 \pm 0.4$ \\
$\mathrm{Cr}$ & 283.56 & 10 & $10.1 \pm 0.2$ & 20 & $20.2 \pm 0.4$ & 40 & $40.4 \pm 0.5$ \\
$\mathrm{Cu}$ & 238.89 & 10 & $9.9 \pm 0.3$ & 20 & $20.1 \pm 0.5$ & 40 & $40.6 \pm 0.5$ \\
$\mathrm{Cd}$ & 214.44 & 5 & $4.9 \pm 0.2$ & 10 & $10.3 \pm 0.3$ & 20 & $20.1 \pm 0.5$ \\
$\mathrm{Fe}$ & 259.94 & 10 & $10.2 \pm 0.2$ & 20 & $20.2 \pm 0.5$ & 40 & $40.6 \pm 0.7$ \\
$\mathrm{Mn}$ & 257.61 & 5 & $5.0 \pm 0.2$ & 10 & $10.2 \pm 0.3$ & 20 & $20.6 \pm 0.6$ \\
$\mathrm{Mo}$ & 202.03 & 20 & $20.1 \pm 0.3$ & 40 & $40.1 \pm 0.5$ & 80 & $82 \pm 1.5$ \\
$\mathrm{Na}$ & 589.89 & 50 & $49.8 \pm 0.3$ & 100 & $101 \pm 4.7$ & 200 & $203 \pm 3.0$ \\
$\mathrm{Nd}$ & 401.23 & 2.5 & $2.4 \pm 0.1$ & 5.0 & $4.8 \pm 0.2$ & 10.0 & $10.3 \pm 0.4$ \\
$\mathrm{Ni}$ & 221.65 & 10 & $10.1 \pm 0.3$ & 20 & $20.3 \pm 0.5$ & 40 & $40.6 \pm 0.7$ \\
$\mathrm{Pd}$ & 324.27 & 5 & $5.1 \pm 0.2$ & 10 & $10.2 \pm 0.3$ & 20 & $20.2 \pm 0.5$ \\
$\mathrm{Pr}$ & 414.31 & 10 & $10.2 \pm 0.3$ & 20 & $20.2 \pm 0.5$ & 40 & $40.5 \pm 0.5$ \\
$\mathrm{Sr}$ & 407.77 & 10 & $10.1 \pm 0.2$ & 20 & $20.2 \pm 0.4$ & 40 & $40.6 \pm 0.7$ \\
$\mathrm{Ce}$ & 393.07 & 2.5 & $2.5 \pm 0.1$ & 5 & $5.1 \pm 0.1$ & 10 & $10.2 \pm 0.4$ \\
$\mathrm{Dy}$ & 353.17 & 2.5 & $2.4 \pm 0.2$ & 5 & $5.2 \pm 0.1$ & 10 & $10.3 \pm 0.3$ \\
$\mathrm{Eu}$ & 420.51 & 2.5 & $2.6 \pm 0.1$ & 5 & $5.1 \pm 0.2$ & 10 & $10.2 \pm 0.3$ \\
$\mathrm{Gd}$ & 379.64 & 2.5 & $2.6 \pm 0.1$ & 5 & $5.2 \pm 0.2$ & 10 & $10.2 \pm 0.5$ \\
$\mathrm{La}$ & 408.67 & 2.5 & $2.6 \pm 0.2$ & 5 & $5.1 \pm 0.1$ & 10 & $10.3 \pm 0.3$ \\
$\mathrm{Pr}$ & 414.31 & 2.5 & $2.7 \pm 0.1$ & 5 & $5.1 \pm 0.1$ & 10 & $10.1 \pm 0.3$ \\
$\mathrm{Sm}$ & 442.44 & 2.5 & $2.5 \pm 0.2$ & 5 & $5.1 \pm 0.1$ & 10 & $10.2 \pm 0.3$ \\
$\mathrm{Y}$ & 224.31 & 2.5 & $2.5 \pm 0.2$ & 5 & $4.9 \pm 0.3$ & 10 & $10.2 \pm 0.3$ \\
$\mathrm{In}$ & 303.94 & 5 & $5.1 \pm 0.2$ & 10 & $10.2 \pm 0.3$ & 10 & $10.2 \pm 0.5$ \\
$\mathrm{Ru}$ & 240.27 & 2.5 & $2.6 \pm 0.2$ & 5 & $5.2 \pm 0.2$ & 10 & $10.1 \pm 0.3$ \\
$\mathrm{Rh}$ & 343.49 & 2.5 & $2.5 \pm 0.2$ & 5 & $5.2 \pm 0.2$ & 10 & $10.2 \pm 0.3$ \\
\hline
\end{tabular}

${ }^{a}$ Analyzed after dilution of samples S-2 ( D.F = 2) and S-3 (D.F = 4). 
permitting the direct determination of trace constituents by ICP-AES. The elements required to be determined in the various HLLWs are of different types of normal elements (such as $\mathrm{Al}, \mathrm{Ba}, \mathrm{Ca}, \mathrm{Mg}, \mathrm{Na}$ ) having simple emission spectra, and transitional elements and lanthanides $(\mathrm{Fe}$, $\mathrm{Cr}$, rare earths, U, etc.) having complex spectra with rich emission lines. Some of the elements such as $\mathrm{Fe}, \mathrm{Na}, \mathrm{Ca}, \mathrm{Ni}$, and uranium are present in significantly larger amounts in HLWs originating from various reactors. Hence, methods need to be developed taking into account the possible interferences from different concomitants.

Using literature data available for spectral interferences of concomitant elements, appropriate spectral lines free from interferences were selected for individual elements. The operating parameters were suitably optimized for each element to obtain the optimum signal-tonoise ratio. A four-point standardization containing the analyte elements of interest at concentrations of $0.5,10,20$, and $50 \mu \mathrm{g} / \mathrm{mL}$ were employed to obtain the calibration curve for all of the analyte elements. In case of uranium, threepoint standardization was employed containing uranium at concentrations of 1,20 , and $50 \mu \mathrm{g} / \mathrm{mL}$. The analytical lines selected for the various elements are included in Table II along with the ICP-AES results obtained for three synthetic samples. The analytical lines for $\mathrm{Ag}, \mathrm{U}$, and $\mathrm{Zr}$ not estimated/present in the synthetic samples are 328.67, 385.96 , and $343.82 \mathrm{~nm}$, respectively.

Method validation was carried out by analysis of several synthetic samples containing elements in the composition range as expected in the respective HLWs in the presence of $10 \mathrm{mg} / \mathrm{mL}$ of uranium. Although it is well known that ICP can be exploited to determine both minor and major constituents in a variety of samples, in complex matrices containing uranium, a prior separation is a pre-requisite for overcoming spectral interferences $(6,8)$. Uranium was separated by extraction with $30 \%$ TBP in do-decane in $4 \mathrm{M} \mathrm{HNO}_{3}$ as mentioned earlier (8-10). The solutions after separation of uranium were dissolved in $25 \mathrm{~mL}$ of $1 \mathrm{M}$ $\mathrm{HNO}_{3}$ for the determination of

TABLE III

SHLW Of Pressurized Heavy Water Reactor (PHWR)

\begin{tabular}{cccc}
\hline Element & $\begin{array}{c}\text { Concentration } \\
(\mu \mathrm{g} / \mathrm{mL})\end{array}$ & $\begin{array}{c}\text { Amount in Sample } \\
(\mathrm{ppm})\end{array}$ & $\begin{array}{c}\text { Average Value } \\
\text { of all Labs }(\mathrm{ppm})\end{array}$ \\
\hline $\mathrm{Ba}$ & $25 \pm 0.09$ & $62.5 \pm 2.25$ & $59.4 \pm 4.6$ \\
$\mathrm{Ce}$ & $8.4 \pm 0.31$ & $209 \pm 7.8$ & $201 \pm 10$ \\
$\mathrm{Cr}$ & $4.4 \pm 0.44$ & $110 \pm 11.0$ & $110 \pm 11.0$ \\
$\mathrm{Fe}$ & $23.2 \pm 2.0$ & $580 \pm 50.0$ & $667 \pm 62$ \\
$\mathrm{La}$ & $5.2 \pm 0.36$ & $130 \pm 9.0$ & $120 \pm 10$ \\
$\mathrm{Mn}$ & $10.8 \pm 1.08$ & $270 \pm 27$ & $306 \pm 42$ \\
$\mathrm{Mo}$ & $5.04 \pm 0.30$ & $126 \pm 7.5$ & $125 \pm 21$ \\
$\mathrm{Na}$ & $58.5 \pm 2.4$ & $4383 \pm 230$ & $4362 \pm 218$ \\
$\mathrm{Nd}$ & $4.3 \pm 0.27$ & $108 \pm 6.8$ & $101 \pm 6.2$ \\
$\mathrm{Ni}$ & $4.1 \pm 0.05$ & $102 \pm 1.05$ & $101 \pm 12$ \\
$\mathrm{Pr}$ & $0.64 \pm 0.05$ & $16.0 \pm 1.3$ & $17.0 \pm 1.4$ \\
$\mathrm{Sm}$ & $0.74 \pm 0.06$ & $18.5 \pm 1.5$ & $16.0 \pm 1.3$ \\
$\mathrm{Sr}$ & $1.47 \pm 0.13$ & $36.8 \pm 3.3$ & $31.5 \pm 3.6$ \\
$\mathrm{Y}$ & $0.07 \pm 0.01$ & $1.75 \pm 0.25$ & $1.62 \pm 0.18$ \\
\hline
\end{tabular}

\footnotetext{
${ }^{a}$ Analyzed after diluting the $25-\mathrm{mL}$ sample solution three times.
}

\section{Atomic Spectroscopy \\ 1 Vol. 33(5), Sept./Oct. 2012}

trace constituents by ICP-AES. The values obtained by ICP-AES for 25 trace metallic constituents in three synthetic samples are listed in Table III. Though Zr was also present in the synthetic samples, its estimates are not included in Table III as it gets extracted with uranium during TBP separation in $\mathrm{HNO}_{3}$.

It was found that the gamma radiation dose given by the HLLW is extremely high $(>1 \mathrm{R} / \mathrm{hr}$ per $\mathrm{mL}$ ) and hence cannot be handled in ICP-AES instruments even after dilution by a factor of 50 , which is the desired level of dilution. In the case of short-cooled HLLW, the gamma dose is mainly due to ${ }^{137} \mathrm{Cs},{ }^{106} \mathrm{Ru}$, ${ }^{144} \mathrm{Ce},{ }^{134} \mathrm{Cs}$, along with Bremsstrahlung from ${ }^{90} \mathrm{Sr}$. In the case of long-cooled HLLW, the dose was attributed mainly to ${ }^{137} \mathrm{Cs}$ and Bremsstrahlung from ${ }^{90} \mathrm{Sr}$. One of the options to reduce the gamma dose of HLLW was the radiochemical separation of the high dose giving radioisotopes. In the case of short-cooled HLLW, the procedure for separation of ${ }^{106} \mathrm{Ru}$ and ${ }^{144} \mathrm{Ce}$ needs to be standardized, which would be taken up as one of the future programs. The standardization of the procedure for separation of Cs from HLLW was carried out by spiking the SHLW with ${ }^{137} \mathrm{Cs}$, ${ }^{85} \mathrm{Sr}$, and other radiotracers, e.g., ${ }^{99} \mathrm{Mo},{ }^{144} \mathrm{Ce},{ }^{106} \mathrm{Ru},{ }^{95} \mathrm{Zr}$, etc. It was found that chlorinated cobalt dicarbolide (CCD) in 20\% nitrobenzene in xylene could quantitatively separate Cs from SHLW. The CCD separation was thus successfully employed for the separation of Cs from the actual HLLW samples (11).

Table III lists the ICP-AES values for trace constituents in PHWR SHLW along with the average value obtained from different laboratories. The value obtained by ICP-AES for the trace constituents in SHLW of RR and FBTR are given in Tables IV and V, respectively. The theoretical expected values of different constituents are also given in these 
tables along with the average values obtained for the analysis of the same SHLW samples by different laboratories as a part of the interlaboratory comparison experiments. The details of the interlaboratory experiments for the characterization of SHLW wastes are presented elsewhere (12) and hence are not discussed here.

Since the elements added in the various SHLWs were different, Tables III, IV, and V list the expected and observed values only for those elements which were present in the respective SHLWs. The estimates obtained in our laboratory are in reasonably good agreement for most of the elements with the average value reported from various laboratories, despite the fact that the standard solutions used by individual laboratories were different and there were slight variations in the instruments/ parameters employed. There is a fairly good agreement between the added and estimated amounts and thus is indicative of the validity of the ICP-AES method proposed for the characterization of HLW samples. The precision of determination for all of the elements are well within $10-15 \%$ for all of the SHLW samples analyzed. The method developed here was used for the analysis of actual HLLW samples received from the Plutonium Reprocessing Plant, Tarapur (PREFRE) and Waste Immobilisation Plant (WIP), Tarapur.

\section{Determination of Elemental Concentrations in the Actual HLLW from PHWR Power Reactor}

$1 \mathrm{~mL}$ from the stock solutions of HLLW, from which the Cs had been separated (HLLW-CCD), was used for the determination of elemental concentrations. The stock solutions were diluted to $25 \mathrm{~mL}$ in $1 \mathrm{M} \mathrm{HNO}_{3}$ for the analysis of trace constituents by sequential ICP-AES using the Jobin-Yvon Ultima instrument.
The values obtained by our laboratory along with the average of the values obtained from four DAE (Department of Atomic Energy) lab- oratories are included in Table VI. In addition, three other HLLW samples from waste tanks at the Tarapur plant were also analyzed by

TABLE IV

Analysis of SHLW of Research Reactor (RR)

\begin{tabular}{ccccr}
\hline Element & $\begin{array}{c}\text { Concen- } \\
\text { tration } \\
(\mu \mathrm{g} / \mathrm{mL})\end{array}$ & $\begin{array}{c}\text { Amount } \\
\text { in Sample } \\
(\mathrm{ppm})\end{array}$ & $\begin{array}{c}\text { Average Value } \\
\text { of all Labs } \\
(\mathrm{ppm})\end{array}$ & $\begin{array}{c}\text { Actual Amount } \\
\text { Added } \\
(\mathrm{ppm})\end{array}$ \\
\hline $\mathrm{Al}$ & $41 \pm 3.6$ & $2050 \pm 180$ & $2167 \pm 192$ & 2205 \\
$\mathrm{Ba}$ & $2.0 \pm 0.20$ & $100 \pm 10.0$ & $96.2 \pm 13.9$ & 90 \\
$\mathrm{Ca}$ & $8.8 \pm 0.66$ & $440 \pm 33.0$ & $402 \pm 28.0$ & 440 \\
$\mathrm{Ce}$ & $1.7 \pm 0.17$ & $85 \pm 8.5$ & $91 \pm 8.9$. & 110 \\
$\mathrm{Cr}$ & $6.4 \pm 0.80$ & $320 \pm 40.0$ & $289 \pm 40$ & 365 \\
$\mathrm{Fe}$ & $25.8 \pm 2.58$ & $1290 \pm 129$ & $1317 \pm 195$ & 1445 \\
$\mathrm{La}$ & $1.2 \pm 0.12$ & $60 \pm 6.0$ & $66 \pm 7.7$ & 75 \\
$\mathrm{Mn}$ & $15.6 \pm 1.40$ & $780 \pm 70.2$ & $759 \pm 58$ & 555 \\
$\mathrm{Mo}$ & $4.2 \pm 0.44$ & $210 \pm 22.0$ & $226 \pm 34.9$ & 265 \\
$\mathrm{Na}$ & $43.0 \pm 4.3$ & $4300 \pm 430$ & $5030 \pm 571$ & 5210 \\
$\mathrm{Ni}$ & $5.0 \pm 0.48$ & $250 \pm 24.0$ & $231+32$ & 270 \\
$\mathrm{Ru}$ & $1.8 \pm 0.17$ & $88.8 \pm 8.5$ & $83.2 \pm 7.0$ & 110 \\
$\mathrm{Sr}$ & $1.2 \pm 0.07$ & $58 \pm 3.5$ & $57.8 \pm 2.9$ & 60 \\
\hline
\end{tabular}

${ }^{a}$ Analyzed after dilution of the original sample 100 times.

Others analyzed after dilution of the original sample 50 times.

TABLE V

SHLW of Fast Breeder Reactor (FBR)

\begin{tabular}{lcccr}
\hline Element & $\begin{array}{c}\text { Concen- } \\
\text { tration } \\
(\mu \mathrm{g} / \mathrm{mL})\end{array}$ & $\begin{array}{c}\text { Amount } \\
\text { in Sample } \\
(\mathrm{ppm})\end{array}$ & $\begin{array}{c}\text { Average Value } \\
\text { of all Labs } \\
(\mathrm{ppm})\end{array}$ & $\begin{array}{c}\text { Actual Amount } \\
\text { Added } \\
(\mathrm{ppm})\end{array}$ \\
\hline $\mathrm{Ag}$ & $6.3 \pm 0.60$ & $6.3 \pm 0.60$ & $7.1 \pm 0.71$ & 8.5 \\
$\mathrm{Ba}^{\mathrm{a}}$ & $15.9 \pm 0.17$ & $159 \pm 1.7$ & $146.0 \pm 20.0$ & 142 \\
$\mathrm{Cd}$ & $14.9 \pm 1.21$ & $14.9 \pm 1.2$ & $12.9 \pm 1.4$ & 13.5 \\
$\mathrm{Ce}$ & $21.1 \pm 1.8$ & $210 \pm 18.0$ & $208.8 \pm 22.7$ & 222 \\
$\mathrm{Cr}$ & $14.6 \pm 1.3$ & $14.6 \pm 1.3$ & $12.1 \pm 1.2$ & 9 \\
$\mathrm{Eu}$ & $12.5 \pm 1.0$ & $12.5 \pm 1.0$ & $13.2 \pm 1.9$ & 15 \\
$\mathrm{Gd}$ & $7.5 \pm 1.0$ & $7.5 \pm 1.0$ & $9.6 \pm 0.48$ & 9.3 \\
$\mathrm{Fe}$ & $85 \pm 7.2$ & $85 \pm 7.2$ & $71.1 \pm 8.5$ & 81.7 \\
$\mathrm{La}$ & $11.2 \pm 1.09$ & $112 \pm 10.9$ & $109.4 \pm 11.5$ & 122 \\
$\mathrm{Mn}$ & $4.5 \pm 0.49$ & $4.5 \pm 0.49$ & $4.1 \pm 0.35$ & 4 \\
$\mathrm{Mo}$ & $1.9 \pm 0.20$ & $1.9 \pm 0.20$ & $1.5 \pm 0.03$ & 2.0 \\
$\mathrm{Nd}$ & $30.2 \pm 0.29$ & $302 \pm 29.1$ & $289 \pm 36.1$ & 348 \\
$\mathrm{Ni}$ & $24.0 \pm 2.2$ & $24.0 \pm 2.2$ & $22.2 \pm 2.7$ & 25 \\
$\mathrm{Pd}$ & $14.0 \pm 0.10$ & $140 \pm 10.1$ & $150 \pm 7.0$ & 168 \\
$\mathrm{Pr}$ & $9.4 \pm 0.98$ & $94 \pm 9.8$ & $88.0 \pm 8.8$ & 120 \\
$\mathrm{Rh}$ & $9.4 \pm 0.90$ & $9.4 \pm 0.90$ & $11.9 \pm 1.1$ & 10 \\
$\mathrm{Ru}$ & $24.1 \pm 0.30$ & $24.1 \pm 0.30$ & $24.6 \pm 0.36$ & 29 \\
$\mathrm{Sm}^{\mathrm{a}}$ & $10.8 \pm 0.09$ & $108 \pm 9.0$ & $93.3 \pm 11.3$ & 99 \\
$\mathrm{Sr}^{\mathrm{a}}$ & $5.3 \pm 0.48$ & $53 \pm 4.8$ & $41.8 \pm 7.2$ & 42 \\
$\mathrm{Y}$ & $21.9 \pm 1.5$ & $21.9 \pm 1.5$ & $22.9 \pm 0.95$ & 24.7 \\
\hline
\end{tabular}

${ }^{a}$ Analyzed after dilution of the original sample 10 times.

Others analyzed directly without dilution. 
ICP-AES. An amount of $0.25 \mathrm{~mL}$ from each of the three WIP waste tanks (No. 8,9,10) were dispensed and diluted to $2.5 \mathrm{~mL}$. A portion of the sample $(0.5 \mathrm{~mL})$ was kept aside for the direct determination of ura-

TABLE VI

Analysis of HLLW Sample 1 from PREFRE, Tarapur, India

\begin{tabular}{lccc}
\hline Element & Concentration & $\begin{array}{c}\text { Amount } \\
\text { in Sample } \\
(\mathrm{ppm})\end{array}$ & $\begin{array}{c}\text { Average Value } \\
\text { of all Labs } \\
(\mathrm{ppm})\end{array}$ \\
\hline $\mathrm{Ba}$ & $3.68 \pm 0.55$ & $92 \pm 13.8$ & $100 \pm 10.0$ \\
$\mathrm{Ce}$ & $6.6 \pm 0.59$ & $165 \pm 14.8$ & $172 \pm 24.3$ \\
$\mathrm{Cr}$ & $6.32 \pm 0.82$ & $158 \pm 20.5$ & $182 \pm 27.3$ \\
$\mathrm{Fe}$ & $26.8 \pm 3.6$ & $670 \pm 90.0$ & $740 \pm 74.2$ \\
$\mathrm{Mn}$ & $0.70 \pm 0.10$ & $17.5 \pm 2.5$ & $16.5 \pm 2.0$ \\
$\mathrm{Mo}$ & $9.76 \pm 0.97$ & $244 \pm 24.3$ & $243 \pm 24.0$ \\
$\mathrm{Pd}$ & $0.6 \pm 0.05$ & $15 \pm 1.25$ & $15.3 \pm 1.40$ \\
$\mathrm{Na}$ & $33.9 \pm 3.40$ & $848 \pm 85.0$ & $852 \pm 86.2$ \\
$\mathrm{Ni}$ & $3.24 \pm 0.36$ & $81 \pm 9.0$ & $90 \pm 11.1$ \\
$\mathrm{Sr}$ & $1.98 \pm 0.20$ & $49.5 \pm 5.0$ & $54.3 \pm 6.5$ \\
$\mathrm{La}$ & $3.32 \pm 0.39$ & $83 \pm 9.75$ & $82 \pm 10.1$ \\
$\mathrm{Nd}$ & $9.96 \pm 1.20$ & $249 \pm 30.0$ & $254 \pm 27.8$ \\
$\mathrm{Y}$ & $1.05 \pm 0.15$ & $26.3 \pm 3.75$ & $27.8 \pm 3.61$ \\
\hline
\end{tabular}

PREFRE : Plutonium reprocessing plant.

TABLE VII

Results of HLLW (Tank 8 from WIP, Tarapur, India) (Concentrations in $\mathrm{mg} / \mathrm{L}$ )

\begin{tabular}{lccc}
\hline Element & $\begin{array}{c}\text { Amount in } \\
\text { Dilute Solution }\end{array}$ & $\begin{array}{c}\text { Final } \\
\text { Amount }\end{array}$ & $\begin{array}{c}\text { Average Value } \\
\text { of all Labs }\end{array}$ \\
\hline $\mathrm{Ba}$ & $17.0 \pm 1.1$ & $170 \pm 11.0$ & $218 \pm 42.0$ \\
$\mathrm{Ce}$ & $21.0 \pm 1.5$ & $210 \pm 15.0$ & $316 \pm 92.4$ \\
$\mathrm{Eu}$ & $1.4 \pm 0.09$ & $14.0 \pm 0.9$ & $14.6 \pm 1.3$ \\
$\mathrm{Gd}$ & $1.1 \pm 0.08$ & $11.0 \pm 0.8$ & $11.4 \pm 0.56$ \\
$\mathrm{La}$ & $13 \pm 0.90$ & $130 \pm 9.0$ & $173 \pm 17.0$ \\
$\mathrm{Mo}$ & $34 \pm 2.2$ & $340 \pm 22.0$ & $365 \pm 33.0$ \\
$\mathrm{Nd}$ & $42.0 \pm 4.1$ & $420 \pm 41.0$ & $430 \pm 62$ \\
$\mathrm{Pd}$ & $1.1 \pm 0.09$ & $11 \pm 0.90$ & $10.2 \pm 1.02$ \\
$\mathrm{Pr}$ & $2.4+0.02$ & $24 \pm 0.20$ & $31.4 \pm 4.7$ \\
$\mathrm{Ru}$ & $7.8 \pm 0.42$ & $78.0 \pm 4.2$ & $83.5 \pm 5.0$ \\
$\mathrm{Sr}$ & $16.0 \pm 0.90$ & $160 \pm 9.0$ & $140.5 \pm 9.8$ \\
$\mathrm{Sm}$ & $12.2 \pm 1.32$ & $122 \pm 13.2$ & $112.6 \pm 12.1$ \\
$\mathrm{Y}$ & $4.6 \pm 0.28$ & $46.0 \pm 2.8$ & $54.0 \pm 4.0$ \\
$\mathrm{Zr}$ & $0.32 \pm 0.04$ & $3.2 \pm 0.40$ & $3.7 \pm 0.50$ \\
$\mathrm{U}^{\mathrm{c}}$ & $8.6 \pm 0.32$ & $8600 \pm 32.0$ & $7883 \pm 394$ \\
$\mathrm{Fe}$ & $20.5 \pm 0.20$ & $2050 \pm 20.0$ & $2786 \pm 28.2$ \\
$\mathrm{Ni}$ & $30.0 \pm 2.8$ & $300 \pm 28.0$ & $433 \pm 116$ \\
$\mathrm{Cr}$ & $52.0 \pm 2.6$ & $520 \pm 26.0$ & $603 \pm 38.2$ \\
$\mathrm{Mn}$ & $47.0 \pm 0.32$ & $470 \pm 32.0$ & $504 \pm 42.0$ \\
$\mathrm{Na}$ & $9.7 \pm 0.75$ & $9700 \pm 750.0$ & $12430 \pm 2360$ \\
\hline $\mathrm{Am}$ & & &
\end{tabular}

${ }^{a}$ Analyzed directly without separation of uranium from $0.5 \mathrm{~mL}$ of the original sample, the dilution factor being 10 for $\mathrm{Zr}$ and 1000 for uranium.

b 100 times dilution after extraction of uranium.

c 1000 times dilution after uranium extraction.

For other elements, dilution factor is 10 (after extraction of uranium).

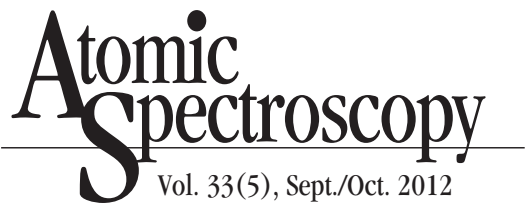

nium and zirconium. ICP-AES analysis for $\mathrm{U}$ and $\mathrm{Zr}$ was done after diluting the samples to $5 \mathrm{~mL}$ in $1 \mathrm{M} \mathrm{HNO}_{3}$. CCD extraction was employed to separate the Cs from $2 \mathrm{~mL}$ of the original left-over sample of HLLW sample-1 as mentioned earlier (Prefre, Tarapur). Uranium was separated by solvent extraction by three contacts with $30 \%$ TBP in dodecane (as mentioned earlier) to minimize the interference from uranium in other elements' emission lines. The samples were then analyzed by ICP-AES after appropriate dilution. 27 elements were assayed in the HLLW which included 19 fission products ( $\mathrm{Sr}, \mathrm{Y}, \mathrm{Zr}, \mathrm{Nb}, \mathrm{Mo}$, $\mathrm{Ru}, \mathrm{Rh}, \mathrm{Pd}, \mathrm{Ag}, \mathrm{Sb}, \mathrm{Ba}, \mathrm{La}, \mathrm{Ce}, \mathrm{Pr}$, $\mathrm{Nd}, \mathrm{Sm}, \mathrm{Eu}, \mathrm{Gd}$ and Dy) +2 additives (Al, Na) and 5 structural materials $(\mathrm{Fe}, \mathrm{Cr}, \mathrm{Ni}, \mathrm{Mn}, \mathrm{Co})$ apart from bulk uranium. The concentration of residual uranium in all of the HLLW samples (i.e. one HLLW of PHWR and three HLLW samples of WIP) after TBP extraction were found to be $<20 \mu \mathrm{g} / \mathrm{mL}$; hence, there is no significant contribution to the intensity in the analyte channels of the different elements of interest. Thus, no correction factors need to be applied in the estimated value of the concentration for various elements in all of the HLLW samples studied. Tables VII to IX give the results obtained by our laboratory on the ICP-AES analysis of the three HLW samples originating from the WIP plant, Tarapur. The average value obtained for various elements from analysis of the same set of samples by four different DAE laboratories are also included in the tables. The overall precision of the determination is within $\pm 15 \%$ R.S.D for the analytes in the four HLLW samples studied.

There is fairly good agreement in the ICP-AES values for all of the elements in the four samples obtained from our laboratory in comparions with the average values reported by the DAE laboratories. It should be noted that all of the laboratories 
adopted the same analytical procedure, used the same analytical lines, though there were some differences in the ICP-AES instruments used by them. The method developed can thus can be employed for the determination of the metallic constituents in HLLW samples originating from nuclear fuels of different burnup and fuel composition.

\section{CONCLUSION}

Analytical methods using inductively coupled plasma atomic emission spectrometry (ICP-AES) have been developed for the determination of metallic constituents in high-level radioactive liquid waste
(HLLW)//simulated high-level waste (SHLW) solutions of different composition. The ICP-AES values obtained by our laboratory for the determination of trace metallic constituents in synthetic SHLW waste solutions corresponding to a pressurized heavy water reactor (PHWR), research reactor (RR), and fast breader ractor (FBR) have shown reasonably good agreement with the experimentally observed values and with the average values reported from four different analytical laboratories of the Division of Atomic Energy (DAE) family. The results obtained with actual HLLW samples are also in agreement with the average values reported. For most of the elements, the method can thus be adopted for the determination of metallic constituents in HLLW solutions.

\section{ACKNOWLEDGMENT}

The authors are thankful to Dr. A. Goswami, Head, Radiochemistry Division, for his constant support during the course of this work.

Received May 25, 2012.
TABLE VIII

Results of HLLW (Tank 9 from WIP, Tarapur, India) (Concentrations in $\mathrm{mg} / \mathrm{L}$ )

\begin{tabular}{cccc}
\hline $\begin{array}{c}\text { Ele- } \\
\text { ment }\end{array}$ & $\begin{array}{c}\text { Amount in } \\
\text { Dilute Solution }\end{array}$ & $\begin{array}{c}\text { Final } \\
\text { Amount }\end{array}$ & $\begin{array}{c}\text { Average Value } \\
\text { of all Labs }\end{array}$ \\
\hline $\mathrm{Ba}$ & $7.7 \pm 0.39$ & $77.0 \pm 3.9$ & $76.3 \pm 5.3$ \\
$\mathrm{Ce}$ & $11.2 \pm 1.8$ & $112 \pm 18.0$ & $128 \pm 19.2$ \\
$\mathrm{Eu}$ & $0.8 \pm 0.07$ & $8.0 \pm 0.70$ & $6.5 \pm 0.65$ \\
$\mathrm{La}$ & $5.9 \pm 0.82$ & $59.0 \pm 8.2$ & $65.2 \pm 9.8$ \\
$\mathrm{Mo}$ & $19.0 \pm 1.9$ & $190 \pm 19.0$ & $215 \pm 25.8$ \\
$\mathrm{Nd}$ & $22.0 \pm 0.8$ & $220 \pm 8.0$ & $228 \pm 11.0$ \\
$\mathrm{Pd}$ & $0.33 \pm 0.03$ & $3.3 \pm 0.30$ & $3.8 \pm 0.50$ \\
$\mathrm{Pr}$ & $1.4 \pm 0.09$ & $14 \pm 0.90$ & $14 \pm 1.20$ \\
$\mathrm{Rh}$ & $0.90 \pm 0.10$ & $9.0 \pm 1.0$ & $11.2 \pm 1.68$ \\
$\mathrm{Ru}$ & $5.5 \pm 0.40$ & $55 \pm 4.0$ & $69 \pm 6.1$ \\
$\mathrm{Sr}$ & $4.4 \pm 0.09$ & $44.0 \pm 0.90$ & $44.0 \pm 1.0$ \\
$\mathrm{Sm}$ & $3.6 \pm 0.25$ & $36.0 \pm 2.5$ & $42.6 \pm 3.8$ \\
$\mathrm{Y}$ & $1.9 \pm 0.12$ & $19.0 \pm 1.2$ & $16.4 \pm 1.4$ \\
$\mathrm{Zr}$ & $0.47 \pm 0.06$ & $4.7 \pm 0.60$ & $4.8 \pm 0.86$ \\
$\mathrm{Ag}$ & $0.30 \pm 0.03$ & $3.0 \pm 0.30$ & $2.8 \pm 0.32$ \\
$\mathrm{U}^{\mathrm{a}}$ & $2.36 \pm 0.18$ & $2360 \pm 180$ & $2520 \pm 242$ \\
$\mathrm{Fe}$ & $7.2 \pm 0.62$ & $720 \pm 62.0$ & $696 \pm 72$ \\
$\mathrm{Ni}$ & $8.8 \pm 0.75$ & $88.0 \pm 7.5$ & $108.0 \pm 18.3$ \\
$\mathrm{Cr}$ & $14.0 \pm 1.3$ & $140 \pm 13.0$ & $171 \pm 25.8$ \\
$\mathrm{Mn}$ & $12.0 \pm 0.70$ & $120.0 \pm 7.0$ & $140 \pm 20.2$ \\
$\mathrm{Na}^{\mathrm{b}}$ & $21.5 \pm 1.5$ & $2150 \pm 150$ & $2576 \pm 248$ \\
\hline $\mathrm{An}$ & & &
\end{tabular}

a Analyzed directly without separation of uranium from $0.5 \mathrm{~mL}$ of the original sample, the dilution factor being 10 for $\mathrm{Zr}$ and 1000 for uranium.

${ }^{b} 100$ times dilution after extraction of uranium.

\section{TABLE IX}

Results of HLLW (Tank 10 from WIP, Tarapur, India (Concentrations in $\mathrm{mg} / \mathrm{L}$ )

\begin{tabular}{cccc}
\hline $\begin{array}{l}\text { Ele- } \\
\text { ment }\end{array}$ & $\begin{array}{c}\text { Amount in } \\
\text { Dilute Solution }\end{array}$ & $\begin{array}{c}\text { Final } \\
\text { Amount }\end{array}$ & $\begin{array}{c}\text { Average Value } \\
\text { of all Labs }\end{array}$ \\
\hline $\mathrm{Ba}$ & $15.0 \pm 1.30$ & $150 \pm 13.0$ & $177 \pm 25.40$ \\
$\mathrm{Ce}$ & $31.0 \pm 4.5$ & $310 \pm 45.0$ & $270 \pm 40.0$ \\
$\mathrm{Eu}$ & $1.5 \pm 0.15$ & $15.0 \pm 1.5$ & $12.2 \pm 1.80$ \\
$\mathrm{Gd}$ & $1.7 \pm 0.10$ & $17.0 \pm 1.0$ & $15.1 \pm 2.10$ \\
$\mathrm{La}$ & $16.0 \pm 1.2$ & $160 \pm 12.0$ & $159 \pm 13.5$ \\
$\mathrm{Mo}$ & $41.0 \pm 3.0$ & $410 \pm 30.0$ & $397 \pm 39.7$ \\
$\mathrm{Nd}$ & $45.0 \pm 3.5$ & $450 \pm 35.0$ & $475 \pm 40.0$ \\
$\mathrm{Pd}$ & $0.80 \pm 0.07$ & $8.0 \pm 0.70$ & $7.3 \pm 0.90$ \\
$\mathrm{Pr}$ & $3.2 \pm 0.40$ & $32.0 \pm 4.0$ & $33.2 \pm 6.0$ \\
$\mathrm{Rh}$ & $1.8 \pm 0.10$ & $18.0 \pm 1.0$ & $19.6 \pm 1.5$ \\
$\mathrm{Ru}$ & $14.0 \pm 0.70$ & $140 \pm 7.0$ & $136 \pm 6.1$ \\
$\mathrm{Sr}$ & $9.8 \pm 0.72$ & $98.0 \pm 7.2$ & $97.4 \pm 12.1$ \\
$\mathrm{Sm}$ & $11.0 \pm 0.65$ & $110 \pm 6.5$ & $99.0 \pm 9.1$ \\
$\mathrm{Y}$ & $4.5 \pm 0.50$ & $45.0 \pm 5.0$ & $42.5 \pm 5.5$ \\
$\mathrm{Zr}$ & $0.41 \pm 0.06$ & $4.1 \pm 0.6$ & $3.7 \pm 0.50$ \\
$\mathrm{U}^{\mathrm{a}}$ & $9.81 \pm 0.82$ & $9810 \pm 820$ & $10656 \pm 960$ \\
$\mathrm{Fe}$ & $44.0 \pm 2.2$ & $4400 \pm 220$ & $4250 \pm 320$ \\
$\mathrm{Co}$ & $0.9 \pm 0,05$ & $9.0 \pm 0.50$ & $9.4 \pm 0.72$ \\
$\mathrm{Ni}^{\mathrm{b}}$ & $38.0 \pm 1.9$ & $380 \pm 19.0$ & $389 \pm 23.3$ \\
$\mathrm{Cr}$ & $7.2 \pm 0.42$ & $720 \pm 42.0$ & $690 \pm 48.3$ \\
$\mathrm{Mn}^{\mathrm{b}}$ & $7.4 \pm 0.33$ & $740 \pm 33.0$ & $713 \pm 42.0$ \\
$\mathrm{Na}^{\mathrm{c}}$ & $36.6 \pm 1.8$ & $18300 \pm 897$ & $17508 \pm 925$ \\
\hline $\mathrm{An}$ & & &
\end{tabular}

${ }^{a}$ Analyzed directly without separation of uranium from $0.5 \mathrm{~mL}$ of the original sample, the dilution factor being 10 for $\mathrm{Zr}$ and 1000 for uranium.

b 100 times dilution after extraction of uranium.

c 500 times dilution after uranium extraction.

For other elements, dilution factor is 10 (after extraction of uranium). 


\section{Atomic Spectroscopy \\ $\bigcirc$ Vol. 33(5), Sept./Oct. 2012}

\section{REFERENCES}

1. J.F. Ahearne, Phys. Today 50, 24 (1997)

2. Debasis Das, S.A. Ansari,

P.K. Mohapatra, G. Mary, K. Radhakrishnan, S.C. TRipathi, and V.K. Manchanda, J. Radioanal. Nucl. Chem. 287, 293 (2011).

3. Tsunekta Banba, Hiromuchi Hagya, et al., Anal. Sciences 14, 389 (1998).

4. Johanna Sabine Becker, Spectrochim. Acta Part B 57, 1805 (2002)

5. S. Fredric Marsh, Anal. Chem. 39, 641 (1967).

6. T.K. Seshagiri, Y. Babu, M.L. Jayanth Kumar, A.G.I. Dalvi, M.D.Sastry and B.D. Joshi, Talanta 31, 773 (1984).

7. AA. Argekar, M.J. Kulkarni, J.N. Mathur and A.G. Page, Talanta 56, 591 (2002).

8. Mithlesh Kumar, M. Mohapatra, Paru J. Purohit, S.K. Thulasidas, T.K. Seshagiri, Neelam Goyal and S.V.Godbole, At. Spectrosc. 31(3), 97 (2010)

9. R.K.Malhotra and K. Satyanarayana, Talanta 50, 601 (1999).

10. V.C. Adya, S.K. Thulasidas, M. Kumar, P.J. Purohit, M. Mohapatra, T.K. Seshagiri and S.V. Godbole, Radiochim. Acta 99, 581 (2011).

11. M.S. Murali, A. Bhattacharayya, D.R. Raut, A.S. Kar, B.S. Tomar and V.K. Manchanda, J. Radioanal. and Nucl. Chem. 2011 (in press).

12. T.K. Seshagiri, S.K. Thulasidas, V.C. Adya, Mithlesh Kumar, K. Radhakrishnan, G. Mary, P.G. Kulkarni, Bharati Bhalerao and D.K. Pant, Nucl. and Radiochem. Symposium, Vol. 2, 420, NUCAR (2011). 